\title{
Synthesis and Structural Study of Some Pyrimidinium Hexafluoridosilicates
}

\author{
Andrej Pevec \\ Faculty of Chemistry and Chemical Technology, University of Ljubljana, Večna pot 113, \\ SI-1000 Ljubljana, Slovenia \\ *Corresponding author: E-mail: andrej.pevec@ fkkt.uni-lj.si
}

Received: 30-09-2014

Dedicated to the memory of Prof. Dr. Jurij V. Brenčič.

\begin{abstract}
The synthesis and spectroscopic characterization of some pyrimidinium hexafluoridosilicate salts with the formula $(\mathrm{RH})_{2}[\mathrm{SiF}]_{6}$ (where $\mathrm{R}=2$-aminopyrimidine (1), cytosine (2) and 5-cyanocytosine (3)) is obtained in the reaction of $\mathrm{SiO}_{2}$ with hydrofluoric acid solution and subsequent addition of 2-aminopyrimidine, cytosine or 4-amino-2-chloropyrimidine-5-carbonitrile. The crystal structures of $\mathbf{1}$ and $\mathbf{3}$ have been determined by single-crystal X-ray diffraction analysis. The combination of $\mathrm{N}-\mathrm{H} \cdots \mathrm{F}$ hydrogen bonds along with $\pi-\pi$ interactions between aromatic rings resulted in supramolecular architecture of cations and anions in the solid state.
\end{abstract}

Keywords: Hexafluoridosilicate, hydrogen bond, pyrimidinium, cytosine, X-ray crystal structure

\section{Introduction}

The ionic compounds with the formula $(\mathrm{RH})_{2}\left[\mathrm{SiF}_{6}\right]$ where $\mathrm{R}$ is pyridine related compounds and $\mathrm{SiF}_{6}^{2-}$ hexafluoridosilicate anion are well documented in the literature. ${ }^{1-11}$ Otherwise the ionic compounds with pyrimidinium cation and some counter anion are relatively rare. ${ }^{12}$ To the best of our knowledge, only one structural report in the CSD includes pyrimidinium fragment and hexafluoridosilicate anion. ${ }^{13}$ The additional nitrogen atom in the pyridine ring results in a decrease of basicity in the pyrimidine ring which has also an influence over the formation of cations in highly acidic media.

Pyrimidine and its derivatives are biologically important components of nucleic acids and coenzymes. Substituted pyrimidines such as cytosine, thymine and uracil have a wide occurrence in living systems. They are also parent compounds of many drugs. 2-chloropyrimidine, for example, is used as starting compound for the synthesis of pharmaceutical products. ${ }^{14}$ Cytosine is a bifunctional molecule (electron-donating and also proton-accepting) which readily forms protonated cationic species. Protonation of cytosine can lead to the formation of hemicytosinium duplex structure in acidic solution which is energetically more favored..$^{15}$ Hydrogen bonds between nucleobases are the most important driving force to make double-strand DNA. ${ }^{16}$ Cytosine can act both as $\mathrm{H}$-bond donor and acceptor via amine and keto group in base pairing with guanine. Cytosinium cations and their derivatives are used also as cationic building blocks together with different anions to generate crystalline supramolecular architectures. Two salts of cytosinium cation with hexachlorido-platinate ${ }^{17}$ and stannate $^{18}$ are known from the literature. The interest for these studies are of great current interest due to the fact that some metal complexes specifically recognize individual nucleobases. ${ }^{19}$ This can play a crucial role in the structure and function of nucleic acid.

Fluoro compounds distinguish from their halogen counterpart mostly due to their different stability and reactivity. Fluorine is a strong acceptor of hydrogen bonds and can play crucial role in building crystal structures. Furthermore, fluoride ligand enables diverse architectures due to its potential to form discrete, mononuclear fluoride species with the predominant octahedral geometry ${ }^{20-22}$ as well as chains, layers and extended three-dimensional structures. ${ }^{23-26}$ This contribution reports the preparation and characterization of 2-aminopyrimidinium- (1) cytosinium- (2) and 5-cyanocytosinium- (3) hexafluoridosilicate. The acid catalyzed hy- 
drolysis of chloro substituent on pyrimidinium ring occurs during the formation of hexafluoridosilicate salt of 3 .

\section{Experimental}

\section{1. General}

Infrared spectra (Nujol mull or solid sample support in Specac Golden Gate Diamond ATR) were recorded on a Perkin-Elmer Spectrum 100 FT-IR spectrometer. NMR spectra were measured on a Bruker Avance III 500 spectrometer operating at $500 \mathrm{MHz}\left({ }^{1} \mathrm{H}\right)$ and $471 \mathrm{MHz}\left({ }^{19} \mathrm{~F}\right)$. Elemental analyses were carried out on a Perkin-Elmer 2400 series II CHNS/O analyzer. High resolution mass spectra were recorded with an Agilent 6224 Accurate Mass TOF LC/MS system. The chemicals were used as purchased: $\mathrm{HF}$ (Aristar), $\mathrm{SiO}_{2}$ (Carl Roth), 2-aminopyrimidine (Fluka), 4-amino-2-hydroxypyrimidine (Fluka), 4-amino-2-chloropyrimidine-5-carbonitrile (Maybridge chemical).

\section{2. Synthesis of Bis(2-aminopyrimidinium) Hexafluoridosilicate (1)}

A silicon dioxide $(1.00 \mathrm{~g} ; 16.6 \mathrm{mmol})$ was slowly added during stirring into plastic beaker containing hydrofluoric acid $(48 \% ; 20 \mathrm{~mL})$. After clarification of solution 2-aminopyrimidine ( $3.26 \mathrm{~g} ; 34.3 \mathrm{mmol}$ ) was slowly added. The mixture was stirred one hour and then filtered. After filtration, the solvent was slowly evaporated from the beaker to yield colorless crystalline product of $\mathbf{1}$ in one week. The crystals were filtered from the mother liquid and dried in air. Yield: $2.04 \mathrm{~g}(37 \%)$. IR (Nujol) $\left(\mathrm{cm}^{-1}\right): 3348,3217,3088\left(v\left(\mathrm{NH}^{+}\right), v\left(\mathrm{NH}_{2}\right)\right), 739(\mathrm{v}(\mathrm{SiF}))$, $477\left(\delta\left(\mathrm{SiF}_{2}\right)\right) .{ }^{1} \mathrm{H}$ NMR $\left(500 \mathrm{MHz}, \mathrm{D}_{2} \mathrm{O}\right): \delta=8.55(\mathrm{~d}, 2 \mathrm{H}$, $\operatorname{Ar} H) ; 7.04$ (t, $1 \mathrm{H}, \mathrm{Ar} H)$ ppm. ${ }^{19} \mathrm{~F}$ NMR $\left(471 \mathrm{MHz}, \mathrm{D}_{2} \mathrm{O}\right)$ : $\delta=-130.0\left(\mathrm{~s}, \mathrm{SiF}_{6}\right) \mathrm{ppm}$. HRMS (ESI+): $\mathrm{m} / \mathrm{z}$ calcd for $\mathrm{C}_{4} \mathrm{H}_{6} \mathrm{~N}_{3}{ }^{+}[\mathrm{M}]^{+}=96.0556$; found: 96.0556. Anal. Calcd. for $\mathrm{C}_{8} \mathrm{H}_{12} \mathrm{~F}_{6} \mathrm{~N}_{6} \mathrm{Si}: \mathrm{C}, 28.74 ; \mathrm{H}, 3.62 ; \mathrm{N}, 25.14$. Found: $\mathrm{C}$, 28.76; H, 3.71; N, 25.22.

\section{3. Synthesis of Bis(cytosinium) Hexafluoridosilicate (2)}

A silicon dioxide $(1.00 \mathrm{~g} ; 16.6 \mathrm{mmol})$ was slowly added during stirring into plastic beaker containing hydrofluoric acid $(48 \% ; 20 \mathrm{~mL})$. After clarification of solution 4-amino-2-hydroxy-pyrimidine $(3.70 \mathrm{~g} ; 33.3$ mmol) was slowly added. The mixture was stirred one hour and then filtered. After filtration, the solvent was slowly evaporated from the beaker to yield colorless crystalline product of $\mathbf{2}$ in one week. The crystals were filtered from the mother liquid and dried in air. Yield: $0.67 \mathrm{~g}$ (11\%). IR (Nujol) $\left(\mathrm{cm}^{-1}\right)$ : 3408, $3240\left(v\left(\mathrm{NH}^{+}\right), v\left(\mathrm{NH}_{2}\right)\right)$, $719(\mathrm{v}(\mathrm{SiF})), 469\left(\delta\left(\mathrm{SiF}_{2}\right)\right) .{ }^{1} \mathrm{H}$ NMR $\left(500 \mathrm{MHz}, \mathrm{D}_{2} \mathrm{O}\right): \delta$ $=7.73(\mathrm{~d}, 1 \mathrm{H}, \operatorname{Ar} H) ; 6.15(\mathrm{~d}, 1 \mathrm{H}, \operatorname{Ar} H) \mathrm{ppm} \cdot{ }^{19} \mathrm{~F}$ NMR $\left(471 \mathrm{MHz}, \mathrm{D}_{2} \mathrm{O}\right): \delta=-129.9\left(\mathrm{~s}, \mathrm{SiF}_{6}\right)$ ppm. HRMS (ESI+): $\mathrm{m} / \mathrm{z}$ calcd for $\mathrm{C}_{4} \mathrm{H}_{6} \mathrm{~N}_{3} \mathrm{O}^{+}[\mathrm{M}]^{+}=112.0505$; found: 112.0510. Anal. Calcd. for $\mathrm{C}_{8} \mathrm{H}_{12} \mathrm{~F}_{6} \mathrm{~N}_{6} \mathrm{O}_{2} \mathrm{Si}$ : C, 26.23; H, 3.30; N, 22.94. Found: C, 26.37; H, 3.10; N, 22.99 .

\section{4. Synthesis of Bis(5-cyanocytosinium) Hexafluoridosilicate (3)}

A silicon dioxide $(0.81 \mathrm{~g} ; 13.5 \mathrm{mmol})$ was slowly added during stirring into plastic beaker containing hydrofluoric acid $(48 \% ; 20 \mathrm{~mL})$. After clarification of solution 4-amino-2-chloropyrimidine-5-carbonitrile $(4.17 \mathrm{~g} ; 27.0 \mathrm{mmol})$ was slowly added. The mixture was stirred one hour and then filtered. After filtration, the solvent was slowly evaporated from the beaker to yield colorless crystalline product of $\mathbf{3}$ after four days. The crystals were filtered from the mother liquid and dried in air. Yield: $1.85 \mathrm{~g}(33 \%)$. IR (Nujol) $\left(\mathrm{cm}^{-1}\right)$ : 3202 $\left(v\left(\mathrm{NH}^{+}\right), v\left(\mathrm{NH}_{2}\right)\right), 726(v(\mathrm{SiF})), 477\left(\delta\left(\mathrm{SiF}_{2}\right)\right),{ }^{1} \mathrm{H} \mathrm{NMR}$ $\left(500 \mathrm{MHz}, \mathrm{D}_{2} \mathrm{O}\right): \delta=8.53(\mathrm{~s}, 1 \mathrm{H}, \mathrm{Ar} H) \mathrm{ppm} .{ }^{19} \mathrm{~F}$ NMR $\left(471 \mathrm{MHz}, \mathrm{D}_{2} \mathrm{O}\right): \delta=-130.0\left(\mathrm{~s}, \mathrm{SiF}_{6}\right)$ ppm. HRMS (ESI+): $\mathrm{m} / \mathrm{z}$ calcd for $\mathrm{C}_{5} \mathrm{H}_{4} \mathrm{~N}_{4} \mathrm{O}^{+}[\mathrm{M}]^{+}=137.0458$; found: 137.0458. Anal. Calcd. for $\mathrm{C}_{10} \mathrm{H}_{10} \mathrm{~F}_{6} \mathrm{~N}_{8} \mathrm{O}_{2} \mathrm{Si}$ : C, 28.85; H, 2.42; N, 26.92. Found: C, 29.02; H, 2.19; N, 27.06 .

\section{5. X-ray Crystallography}

Crystal data and refinement parameters of compound $\mathbf{1}$ and $\mathbf{3}$ are listed in Table 1 . The X-ray intensity data were collected at room temperature on a Nonius Kappa CCD diffractometer equipped with graphite-monochromated $\mathrm{Mo}-K_{\alpha}$ radiation $(\lambda=0.71073 \AA)$ for $\mathbf{1}$ and on Agilent SuperNova dual source with Atlas detector equipped with mirror-monochromated Mo- $K_{\alpha}$ radiation $(\lambda=0.71073 \AA)$ at $150 \mathrm{~K}$ for 3 . The data were processed using DENZO ${ }^{27}(\mathbf{1})$ or CRYSALIS PRO $^{28}(\mathbf{3})$. The structures were solved by direct methods using SIR- $92^{29}$ and refined against $F^{2}$ on all data by a full-matrix least squares procedure with SHELXL-97. ${ }^{30}$ All non-hydrogen atoms were refined anisotropically. All hydrogen atoms bonded to carbon were included in the model at geometrically calculated positions and refined using a riding model. The nitrogen bonded hydrogen atoms were located in the difference map and refined with the distance restraints (DFIX) with $\mathrm{N}-\mathrm{H}=0.86$ for 1 and 0.88 for 3 and with $U_{\text {iso }}(\mathrm{H})=1.2 U_{\text {eq }}(\mathrm{N})$ for both cases. The figures were prepared using DIAMOND 3.2 software. ${ }^{31}$

CCDC - 1026057 and 1026058 contains the supplementary crystallographic data for $\mathbf{1}$ and $\mathbf{3}$, respectively. These data can be obtained free of charge from The Cambridge Crystallographic Data Centre via www.ccdc.cam. ac.uk/data_request/cif. 
Table 1. Experimental data for the X-ray diffraction studies on compounds $\mathbf{1}$ and $\mathbf{3}$.

\begin{tabular}{lll}
\hline & $\mathbf{1}$ & $\mathbf{3}$ \\
\hline formula & $\mathrm{C}_{8} \mathrm{H}_{12} \mathrm{~F}_{6} \mathrm{~N}_{6} \mathrm{Si}$ & $\mathrm{C}_{10} \mathrm{H}_{10} \mathrm{~F}_{6} \mathrm{~N}_{8} \mathrm{O}_{2} \mathrm{Si}$ \\
$\mathrm{Fw}\left(\mathrm{g} \mathrm{mol}^{-1}\right)$ & 334.33 & 416.35 \\
crystal size $(\mathrm{mm})$ & $0.25 \times 0.20 \times 0.10$ & $0.30 \times 0.10 \times 0.10$ \\
crystal color & colourless & colourless \\
crystal system & monoclinic & triclinic \\
space group & $P 2_{1} / a$ & $P-1$ \\
$a(\AA)$ & $7.6053(4)$ & $6.53797(14)$ \\
$b(\AA)$ & $10.2268(4)$ & $13.8864(5)$ \\
$c(\AA)$ & $8.1915(4)$ & $16.9704(6)$ \\
$\alpha\left(^{\circ}\right)$ & 90 & $93.464(3)$ \\
$\beta\left(^{\circ}\right)$ & $96.805(3)$ & $90.638(2)$ \\
$\gamma\left({ }^{\circ}\right)$ & 90 & $92.089(2)$ \\
$V\left(\AA^{3}\right)$ & $632.63(5)$ & $1536.75(8)$ \\
$Z$ & 2 & 4 \\
calcd density $\left(\mathrm{g} \mathrm{cm}^{-3}\right)$ & 1.755 & 1.800 \\
$F(000)$ & 340 & 840 \\
$T(\mathrm{~K})$ & $293(2)$ & $150(2)$ \\
no. of collected reflns & 2739 & 14381 \\
no. of independent reflns & 1437 & 7059 \\
$R_{\text {int }}$ & 0.0171 & 0.0261 \\
no. of reflns observed & 1173 & 5878 \\
no. parameters & 106 & 535 \\
$R[I>2 \sigma(I)]^{a}$ & 0.0348 & 0.0482 \\
$w R_{2}(\text { all data })^{b}$ & 0.0934 & 0.1257 \\
$G o o f, S^{c}$ & 1.039 & 1.069 \\
maximum/minimum residual & $+0.27 /-0.25$ & $+0.71 /-0.32$ \\
electron density $\left(\mathrm{e} \AA^{-3}\right)$ & & \\
\hline & &
\end{tabular}

${ }^{a} R=\Sigma|| F_{\mathrm{o}}|-| F_{\mathrm{c}} \| / \Sigma\left|F_{\mathrm{o}}\right| \cdot{ }^{b} w R_{2}=\left\{\sum\left[w\left(F_{\mathrm{o}}{ }^{2}-F_{\mathrm{c}}{ }^{2}\right)^{2}\right] / \Sigma\left[w\left(F_{\mathrm{o}}{ }^{2}\right)^{2}\right]\right\}^{1 / 2} \cdot{ }^{c} S=\left\{\sum\left[w\left(F_{\mathrm{o}}{ }^{2}-F_{\mathrm{c}}{ }^{2}\right)^{2}\right] /(n / p\}^{1 / 2}\right.$ whe re $n$ is the number of reflections and $p$ is the total number of parameters refined.

\section{Results and Discussion}

Hydrofluoric acid has the ability to dissolve silicon dioxide and hexafluoridosilicic acid is formed (Scheme 1). The treatment of this solution with relevant $N$-base results in the formation of hexafluoridosilicate salts. The use of pyrimidinium derivatives results in the formation of three new hexafluoridosilicate salts. The hexafluoridosilicate salts with substituted pyrimidinium cations 1-3 with the general formula $(\mathrm{RH})_{2}\left[\mathrm{SiF}_{6}\right](\mathrm{R}=2$-aminopyrimidine (1), cytosine (2) and 5-cyanocytosine (3)) were prepared at room temperature according to the procedure, reported for the synthesis of methyl substituted pyridinium hexafluoridosilicates. ${ }^{4}$ The molar ratios between $\mathrm{SiO}_{2}$ and related pyrimidines were in all cases 1:2 (Scheme 1). Colorless crystals were obtained by slow solvent evaporation at room temperature. All of the compounds were characterized by ${ }^{1} \mathrm{H}$ and ${ }^{19} \mathrm{~F}$ NMR and IR spectroscopy, elemental analysis, mass spectrometry and for $\mathbf{1}$ and $\mathbf{3}$ also with single-crystal X-ray structural analysis (see Figure S1 and Figure S2 in Supplementary Material).

Compound 1 crystalizes in the monoclinic $P 2_{1} / \mathrm{a}$ space group. Selected bond lengths and angles are given
$\mathrm{SiO}_{2}+6 \mathrm{HF} \longrightarrow \mathrm{H}_{2}\left(\mathrm{SiF}_{6}\right)+2 \mathrm{H}_{2} \mathrm{O}$

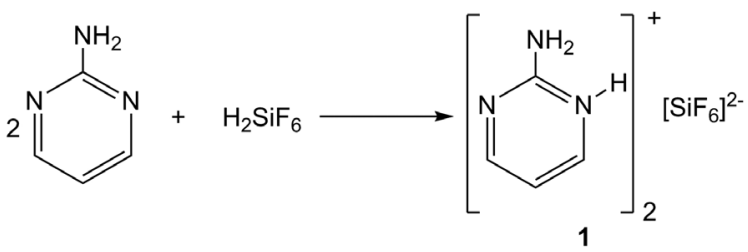<smiles></smiles><smiles>N#Cc1cnc(Cl)nc1N</smiles>

Scheme 1: 
in Table 2. The asymmetric unit consists of one half of hexafluoridosilicate anion on special positions on an inversion center and one 2-aminopyrimidinium cation occupying the general positions (Figure $\mathrm{S} 1$ ). The $\mathrm{Si}-\mathrm{F}$ distances in $\left[\mathrm{SiF}_{6}\right]^{2-}$ anion are from 1.674(1) to 1.6876(9) $\AA$ and bond angles within anion are close to $90^{\circ}$ and $180^{\circ}$ (Figure 1). Proton transfer to the one of pyrimidine nitrogen atom in $\mathbf{1}$ is clearly indicated by the widened $\mathrm{C} 1-\mathrm{N} 1-\mathrm{C} 4$ bond angle in the aromatic ring $\left(121.48(15)^{\circ}\right)$ in contrast to the non-protonated nitrogen atom with the angle $\mathrm{C} 1-\mathrm{N} 2-\mathrm{C} 2\left(117.27(15)^{\circ}\right)$. All fluorine atoms from each octahedral $\left[\mathrm{SiF}_{6}\right]^{2-}$ anion are involved in $\mathrm{N}-\mathrm{H} \cdots \mathrm{F}$ hydrogen bonding. The protonated heterocyclic nitrogen atom together with the amino group are efficient three hydrogen bond donors resulting in two dimensional layers which are perpendicular to the $c$-axis in the crystal structure (Table 3 ). The layers are further stabilized by the noncovalent $\pi-\pi$ interactions of $3.489 \AA$ (Figure 2 and Table S1 in the Supplementary Material).

Compound 2 crystalizes in monoclinic $C 2 / m$ space group but due to the poor crystallographic data the structure was not suitable for the refinement. Elemental analysis and mass spectra prove the formula of compound with two cytosinium cations per one hexafluoridosilicate anion.

Compound $\mathbf{3}$ is an example of acid catalyzed hydrolysis of chloro substituted pyrimidine well known from the literature. ${ }^{32}$ Chloro substituent on position 2 of pyrimidine ring is highly prone to water substitution reaction in acidic HF medium where the first step probably is the protonation of one heterocyclic nitrogen atom. This
Table 2. Selected bond lengths ( $(\AA)$ and angles $\left(^{\circ}\right)$ for $\mathbf{1}$ and $\mathbf{3}$.

\begin{tabular}{|c|c|c|c|}
\hline \multicolumn{4}{|l|}{1} \\
\hline Si1-F1 & $1.676(1)$ & F1-Si1-F2 & $89.59(5)$ \\
\hline Si1-F2 & $1.6876(9)$ & $\mathrm{F} 1-\mathrm{Si} 1-\mathrm{F} 1^{\mathrm{i}}$ & 180.0 \\
\hline Si1-F3 & $1.674(1)$ & $\mathrm{N} 1-\mathrm{C} 1-\mathrm{N} 2$ & $120.7(2)$ \\
\hline $\mathrm{N} 1-\mathrm{C} 1$ & $1.351(2)$ & $\mathrm{N} 1-\mathrm{C} 1-\mathrm{N} 3$ & $119.5(2)$ \\
\hline $\mathrm{N} 1-\mathrm{C} 4$ & $1.347(2)$ & $\mathrm{N} 2-\mathrm{C} 1-\mathrm{N} 3$ & $119.8(2)$ \\
\hline $\mathrm{N} 2-\mathrm{C} 1$ & $1.343(2)$ & $\mathrm{N} 2-\mathrm{C} 1-\mathrm{O} 1$ & $122.0(2)$ \\
\hline $\mathrm{N} 2-\mathrm{C} 2$ & $1.313(2)$ & $\mathrm{C} 1-\mathrm{N} 1-\mathrm{C} 4$ & $121.5(2)$ \\
\hline N3-C1 & $1.313(2)$ & $\mathrm{C} 1-\mathrm{N} 2-\mathrm{C} 2$ & $117.3(2)$ \\
\hline \multicolumn{4}{|l|}{3} \\
\hline Si1-F1 & $1.680(2)$ & F1-Si1-F2 & $88.68(8)$ \\
\hline Si1-F2 & $1.721(1)$ & F1-Si1-F4 & $177.93(8)$ \\
\hline Si1-F3 & $1.671(2)$ & $\mathrm{N} 1-\mathrm{C} 1-\mathrm{N} 2$ & $114.2(2)$ \\
\hline Si1-F4 & $1.679(2)$ & $\mathrm{N} 2-\mathrm{C} 2-\mathrm{N} 3$ & $119.6(2)$ \\
\hline Si1-F5 & $1.671(1)$ & $\mathrm{N} 1-\mathrm{C} 1-\mathrm{O} 1$ & $123.7(2)$ \\
\hline Si1-F6 & $1.688(2)$ & $\mathrm{C} 1-\mathrm{N} 1-\mathrm{C} 4$ & $123.5(2)$ \\
\hline Si1-F7 & $1.681(2)$ & $\mathrm{C} 1-\mathrm{N} 2-\mathrm{C} 2$ & $126.0(2)$ \\
\hline Si1-F8 & $1.692(2)$ & $\mathrm{C} 3-\mathrm{C} 2-\mathrm{N} 3$ & $124.3(2)$ \\
\hline Si1-F9 & $1.669(2)$ & $\mathrm{C} 3-\mathrm{C} 5-\mathrm{N} 4$ & $176.4(3)$ \\
\hline Si1-F10 & $1.670(2)$ & & \\
\hline Si1-F11 & $1.719(2)$ & & \\
\hline Si1-F12 & $1.682(2)$ & & \\
\hline $\mathrm{N} 1-\mathrm{C} 1$ & $1.378(3)$ & & \\
\hline $\mathrm{N} 1-\mathrm{C} 4$ & $1.337(3)$ & & \\
\hline $\mathrm{N} 2-\mathrm{C} 1$ & $1.383(3)$ & & \\
\hline $\mathrm{N} 2-\mathrm{C} 2$ & $1.353(3)$ & & \\
\hline N3-C2 & $1.305(3)$ & & \\
\hline N4-C5 & $1.145(3)$ & & \\
\hline $\mathrm{O} 1-\mathrm{C} 1$ & $1.211(3)$ & & \\
\hline C3-C5 & $1.430(3)$ & & \\
\hline
\end{tabular}

Symmetry code: (i) $-x+1,-y+1,-z$.

Table 3. Hydrogen-bonding geometry for $\mathbf{1}$ and $\mathbf{3}$.

\begin{tabular}{|c|c|c|c|c|c|}
\hline D-HaA & $d(\mathbf{D}-\mathbf{H}) / \AA$ & $d(\mathbf{H} \cdots \mathbf{A}) / \AA$ & $d(\mathrm{D} \cdots \mathrm{A}) / \AA$ & $<\left.($ DHA $)\right|^{\circ}$ & $\begin{array}{c}\text { Symmetry transformation } \\
\text { for acceptors }\end{array}$ \\
\hline \multicolumn{6}{|l|}{1} \\
\hline N1-H1N...F2 & $0.84(2)$ & $1.85(2)$ & $2.676(2)$ & $170(2)$ & $x-1, y, z$ \\
\hline $\mathrm{N} 3-\mathrm{H} 3 \mathrm{~A} \cdots \mathrm{F} 1$ & $0.85(2)$ & $2.20(2)$ & $3.011(2)$ & $160(2)$ & $x-1 / 2,-y+3 / 2, z$ \\
\hline N3-H3B $\cdots$ F3 & $0.84(2)$ & $2.04(2)$ & $2.876(2)$ & $172(2)$ & $-x,-y+1,-z$ \\
\hline \multicolumn{6}{|l|}{3} \\
\hline N1-H1N ‥F9 & $0.87(2)$ & $2.06(2)$ & $2.915(2)$ & $167(3)$ & \\
\hline N2-H2N ‥F6 & $0.85(2)$ & $1.84(2)$ & $2.642(2)$ & $158(3)$ & \\
\hline N3-H3A $\cdots$ F1 & $0.87(2)$ & $1.96(2)$ & $2.829(3)$ & $172(3)$ & $x-1, y,-z$ \\
\hline N3-H3B $\cdots$ F2 & $0.88(2)$ & $2.16(2)$ & $3.009(3)$ & $162(3)$ & \\
\hline N5-H5N ‥F5 & $0.87(2)$ & $2.01(2)$ & $2.861(2)$ & $164(3)$ & \\
\hline N6-H6N $\cdots F 8$ & $0.85(2)$ & $1.79(2)$ & $2.636(2)$ & $180(3)$ & $x+1, y, z$ \\
\hline N7-H7A $\cdots$ F12 & $0.86(2)$ & $2.16(2)$ & $2.912(3)$ & $145(3)$ & \\
\hline N7-H7B $\cdots$ F11 & $0.86(2)$ & $2.01(2)$ & $2.864(2)$ & $175(3)$ & $x+1, y, z$ \\
\hline N9-H9N…O3 & $0.91(3)$ & $1.91(3)$ & $2.809(3)$ & $172(3)$ & $-x,-y+2,-z+2$ \\
\hline N10-H10N ‥F2 & $0.89(2)$ & $1.78(2)$ & $2.659(2)$ & $173(3)$ & \\
\hline N11-H11A $\cdots$ F3 & $0.90(2)$ & $1.86(2)$ & $2.748(3)$ & $172(3)$ & \\
\hline N11-H11B ‥F7 & $0.88(2)$ & $2.00(2)$ & $2.829(3)$ & $158(3)$ & $x+1, y+1, z$ \\
\hline N13-H13N‥O4 & $0.86(2)$ & $1.96(2)$ & $2.812(3)$ & $169(3)$ & $-x-1,-y+2,-z+1$ \\
\hline N14-H14N ‥F11 & $0.86(2)$ & $1.89(2)$ & $2.729(3)$ & $165(3)$ & $x, y+1, z$ \\
\hline N15-H15A ‥F4 & $0.90(2)$ & $1.93(2)$ & $2.740(2)$ & $149(3)$ & \\
\hline N15-H15B $\cdots$ F10 & $0.87(2)$ & $1.96(2)$ & $2.810(3)$ & $167(3)$ & $x, y+1, z$ \\
\hline
\end{tabular}




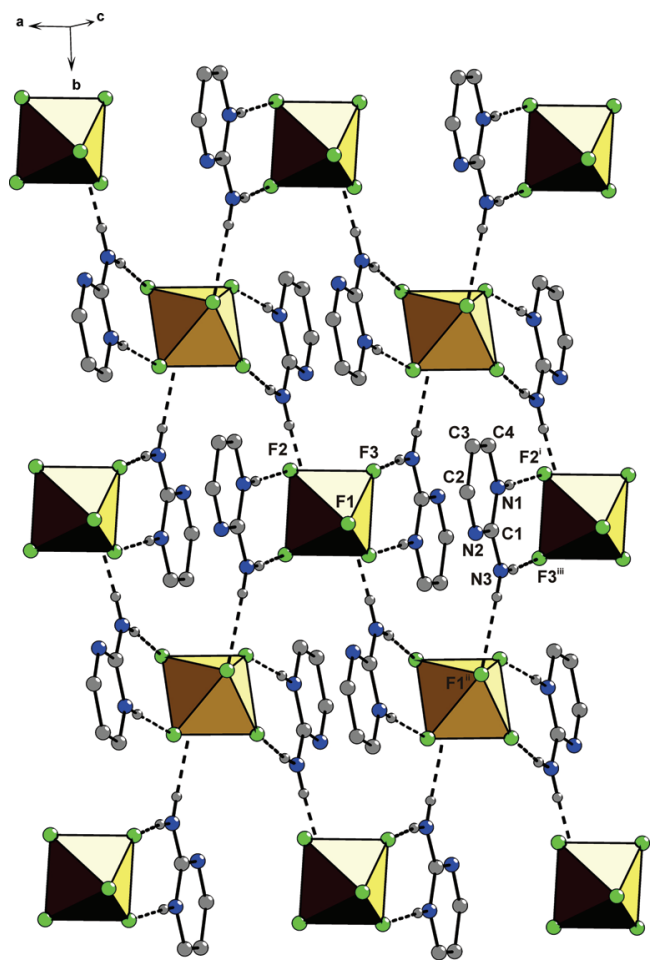

Figure 1. 2D layered structure and atom numbering scheme of $\mathbf{1}$. The hydrogen atoms on aromatic rings have been removed for clarity. Symmetry codes: (i) $x-1, y, z$; (ii) $x-1 / 2,-y+3 / 2, z$; (iii) $-x$, $-y+1,-z$.

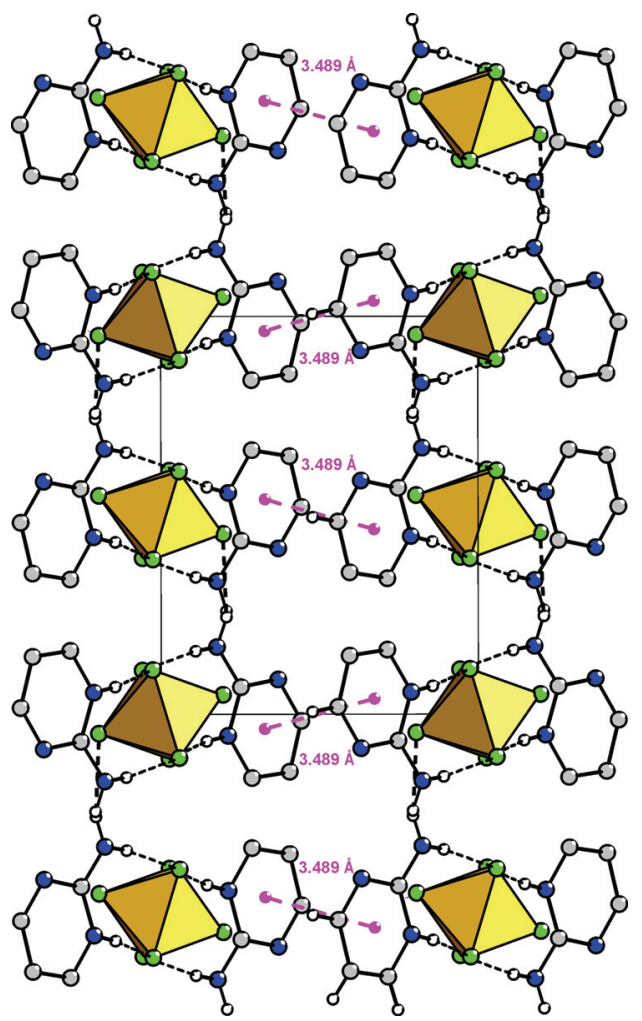

Figure 2. Stacking diagram of 1 presenting the $\pi-\pi$ interactions between the 2-aminopyrimidinium cations. The hydrogen atoms on aromatic rings have been omitted for clarity. results in increased electrophilicity on position 2 of the aromatic ring and readily substitution of chloride with water molecule then occurs. Subsequent tautomerization affords cyano-substituted cytosinium cation which is an efficient building bloc in $\mathrm{N}-\mathrm{H}$... F hydrogen bonding supramolecular array of hexafluoridosilicate.

Compound 3 crystalize in triclinic $P-1$ space group. Selected bond lengths and angles are given in Table 2. The asymmetric unit consists of two hexafluoridosilicate anions and four cyano-substituted cytosinium cations (Figure S2). All atoms occupy general positions in the crystal structure. The $\mathrm{Si}-\mathrm{F}$ distances of both crystallographically

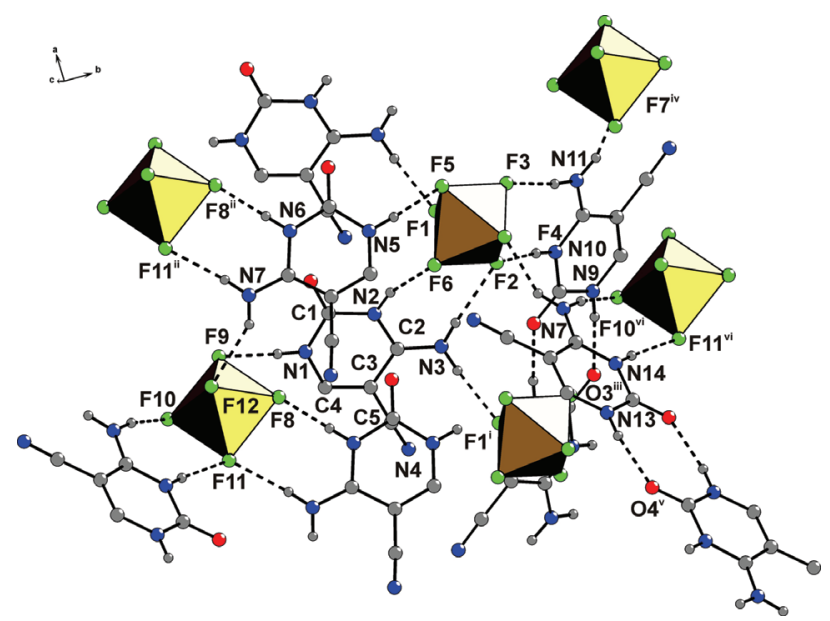

Figure 3. Detail of the crystal packing of $\mathbf{3}$ and atom numbering scheme. Hydrogen atoms not involved in hydrogen bonding have been omitted for clarity. Symmetry codes: (i) $x-1, y,-z$; (ii) $x+1, y$, $z$; (iii) $-x,-y+2,-z+2$; (iv) $x+1, y+1, z$; (v) $-x-1,-y+2,-z+1$, (vi) $x$, $y+1, z$.

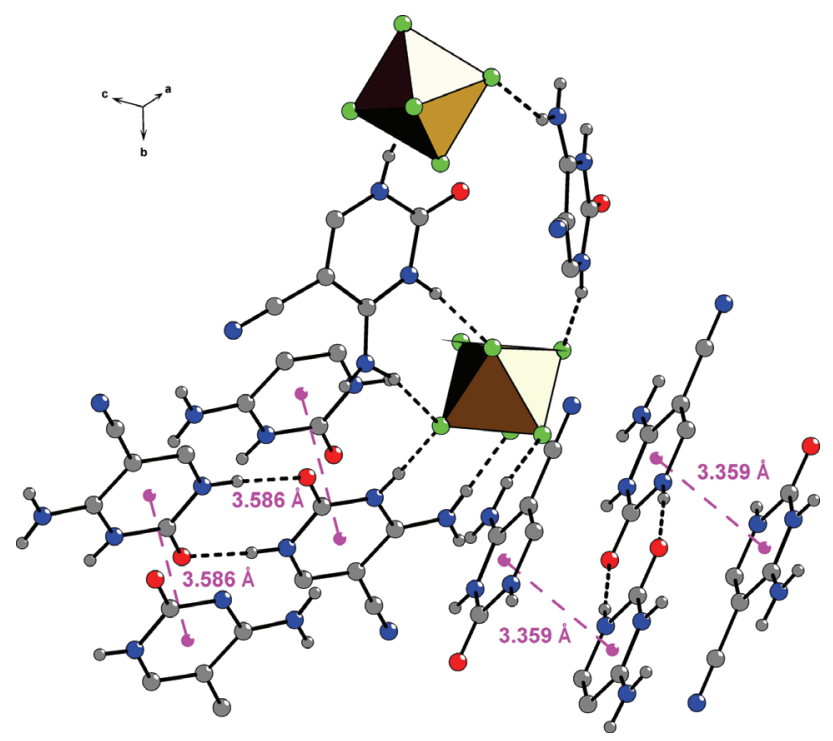

Figure 4. Detail of the crystal packing of 3 depicting the $\pi-\pi$ interactions between aromatic rings. Hydrogen atoms not involved in hydrogen bonding have been omitted for clarity. 
independent $\left[\mathrm{SiF}_{6}\right]^{2-}$ anions are from 1.671(1) to 1.721(1) $\AA$ and bond angles within anion are close to $90^{\circ}$ and $180^{\circ}$. All fluorine atoms from both octahedra in asymmetric unit are involved in $\mathrm{N}-\mathrm{H} \cdots \mathrm{F}$ hydrogen-bonding (Table 3 ). Both protonated heterocyclic nitrogen atoms together with amino nitrogen are efficient donors of $\mathrm{N}-\mathrm{H} \cdots \mathrm{F}$ or even $\mathrm{N}-\mathrm{H} \cdots \mathrm{O}$ hydrogen bonds forming three dimensional structure (Figure 3). These charge assisted hydrogen bonding network is further stabilized by two different $\pi-\pi$ interactions between aromatic rings of 3.359 and $3.586 \AA$, respectively (Figure 4 and Table S1 in the Supplementary Material).

\section{Conclusions}

In summary, three new hexafluoridosilicate salts with pyrimidinium related cations are described. The hydrogen-bonding network structure led to the formation of two- or three-dimensional supramolecular arrays assisted with additional $\pi-\pi$ interactions. It is obvious from Figs. 2 and 4 that the dipoles of contiguous rings are in approximate antiparallel alignment. Geometry of $\mathrm{SiF}_{6}{ }^{2-}$ anion in $\mathbf{1}$ is nearly a perfect octahedron (within the experimental error), but in $\mathbf{3}$ it is quite distorted. One of the $\mathrm{Si}-\mathrm{F}$ bond lengths in both octahedra of asymmetric unit is about $0.04 \AA$ longer than other bonds. This distortion can be explained with the fact that corresponding F2 and F11 atoms are acceptors of two hydrogen bonds in the crystal structure. An acid catalyzed hydrolysis of chloro substituent on pyrimidine ring is demonstrated.

\section{Acknowledgement}

This work was supported by the Grant P1-0175-103 from the Ministry of Higher Education, Science and Technology, Republic of Slovenia and the Slovenian Research Agency and partly supported through the infrastructure of the EN-FIST Centre of Excellence, Ljubljana. Author also thank to Dr. J. Košmrlj for his extremely helpful comments.

\section{References}

1. V. O. Gelmboldt, E. V. Ganin, K. V. Domasevitch, Acta Cryst. 2007, C63, o530-o534.

2. P. Byrne, D. R. Turner, G. O. Lloyd, N. Clarke, J. W. Steed, Cryst. Growth Des. 2008, 8, 3335-3344.

http://dx.doi.org/10.1021/cg800247f

3. V. O. Gelmboldt, L. V. Koroeva, E. V. Ganin, M. S. Fonari, M. M. Botoshansky, A. A. Ennan, J. Fluorine Chem. 2008, 129, 632-636.

http://dx.doi.org/10.1016/j.jfluchem.2008.05.006

4. A. Pevec, A. Demšar, J. Fluorine Chem. 2008, 129, 707-712. http://dx.doi.org/10.1016/j.jfluchem.2008.06.022
5. V. O. Gelmboldt, L. Kh. Minacheva, E. V. Ganin, V. S. Sergienko, Russ. J. Inorg. Chem. 2008, 53, 875-878. http://dx.doi.org/10.1134/S0036023608060107

6. A.-R. Wang, Acta Cryst. 2008, E64, o2405.

7. V. O. Gelmboldt, E. V. Ganin, M. S. Fonari, L. V. Koroeva, Y. E. Ivanov, M. M. Botoshansky, J. Fluorine Chem. 2009, 130, 428-433. http://dx.doi.org/10.1016/j.jfluchem.2009.01.007

8. V. O. Gelmboldt, E. V. Ganin, L. K. Minacheva, L. V. Koroeva, V. S. Sergienko, Russ. J. Inorg. Chem. 2010, 55, 12091215. http://dx.doi.org/10.1134/S0036023610080097

9. S. Marivel, M. Arunachalam, P. Ghosh, Cryst. Growth Des. 2011, 11, 1642-1650. http://dx.doi.org/10.1021/cg101595n

10. M. Ratajczak-Sitarz, A. Katrusiak, Z. Dega-Szafran, G. Stefañski, Cryst. Growth Des. 2013, 13, 4378-4384. http://dx.doi.org/10.1021/cg400752y

11. V. O. Gelmboldt, E. V. Ganin, M. M. Botoshansky, V. Y. Anisimov, O. V. Prodan, V. C. Kravtsov, M. S. Fonari, J. Fluorine Chem. 2014, 160, 57-63. http://dx.doi.org/10.1016/j.jfluchem.2014.01.014

12. CSD database, version 5.35, update: May 2014.

13. V. Sethuraman, S. Nithianantham, P. T. Muthiah, J. Fluorine Chem. 2012, 135, 38-44. http://dx.doi.org/10.1016/j.jfluchem.2011.07.027

14. V. J. Rani, R. Aminedi, K. Polireddy, K. Jagadeeswarareddy, Arch. Pharm. Chem. Life Sci. 2012, 345, 663-669. http://dx.doi.org/10.1002/ardp.201200021

15. S. R. Perumalla, V. R. Pedireddi, C. C. Sun, Cryst. Growth Des. 2013, 13, 429-432. http://dx.doi.org/10.1021/cg3014915

16. J. D. Watson, F. H. Crick, Nature 1953, 171, 964-976. http://dx.doi.org/10.1038/171964b0

17. G. Valle, R. Ettorre, Z. Kristallogr.-New Cryst. Struct. 1998, 213, 327-328. http://dx.doi.org/10.1524/ncrs.1998.213.14.341

18. S. Bouacida, H. Merazig, A. Beghidja, C. Beghidja, Acta Cryst. 2005, E61, m2072-m2074.

19. M. A. Salam, K. Aoki, Inorg. Chim. Acta 2000, 311, 15-24. http://dx.doi.org/10.1016/S0020-1693(00)00297-8

20. A. Pevec, M. Tekavec, A. Demšar, Polyhedron 2011, 30, 549-555. http://dx.doi.org/10.1016/j.poly.2010.11.018

21. F. Tamadon, S. Seidel, K. Seppelt, Acta Chim. Slov. 2013, 60, 491-494.

22. B. Ardan, Y. Slyvka, E. Goreshnik, M. Mys'kiv, Acta Chim. Slov. 2013, 60, 484-490.

23. I. M. Shlyapnikov, H. P. A. Mercier, E. A. Goreshnik, G. J. Schrobilgen, Z. Mazej, Inorg. Chem. 2013, 52, 8315-8326. http://dx.doi.org/10.1021/ic302468j

24. M. Tramšek, E. Goreshnik, G. Tavčar, Z. Mazej, Acta Chim. Slov. 2013, 60, 537-542.

25. M. Lozinšek, E. Goreshnik, B. Žemva, Acta Chim. Slov. 2014, 61, 542-547.

26. I. M. Shlyapnikov, E. A. Goreshnik, Z. Mazej, Chem. Commun. 2013, 49, 2703-2705. http://dx.doi.org/10.1039/c3cc40756j

27. Z. Otwinowsky, W. Minor, Methods Enzymol. 1997, 276, 
307-326. http://dx.doi.org/10.1016/S0076-6879(97)76066-X

28. Oxford Diffraction, CrysAlis PRO, Oxford Diffraction Ltd., Yarnton, England, 2009.

29. A. Altomare, G. Cascarano, C. Giacovazzo, A. Guagliardi, J. Appl. Crystallogr. 1993, 26, 343-350.

http://dx.doi.org/10.1107/S0021889892010331
30. G. M. Sheldrick, Acta. Cryst. 2008, A64, 112-122. http://dx.doi.org/10.1107/S0108767307043930

31. DIAMOND, v3.2, Crystal Impact GbR, Bonn, Germany.

32. G. W. Rewcastle, Pyrimidines and their Benzo Derivatives. In Comprehensive Heterocyclic Chemistry III; A. R. Katritzky, C. A. Ramsden, E. F. V. Scriven, R. J. K. Taylor, Eds.; Elsevier: New York, NY, USA, 2008; Volume 8.02, pp. 117272.

\section{Povzetek}

Pri reakciji med silicijevim dioksidom in 2-aminopirimidinom, citozinom in 4-amino-2-kloropirimidin-5-carbonitrilom v fluorovodikovi kislini smo izolirali tri ionske spojine s splošno formulo $(\mathrm{RH})_{2}[\mathrm{SiF}]_{6}(\mathrm{R}=2$-aminopirimidin (1), citozin (2) in 5-cianocitozin (3)). Kristalni strukturi spojin $\mathbf{1}$ in $\mathbf{3}$ sta bili določeni s pomočjo rentgenske strukturne analize. Kombinacija $\mathrm{N}-\mathrm{H} \cdots \mathrm{F}$ in $\mathrm{N}-\mathrm{H} \cdots \mathrm{O}$ vodikovih vezi ter $\pi-\pi$ interakcij med aromatskimi obroči daje supramolekularno razporeditev kationov in anionov $\mathrm{v}$ trdnem stanju. 